\title{
Phenotypic and Genotypic Analysis of a U.S. Native Fine-leaved Festuca Population Reveals Its Potential Use for Low-input Urban Landscapes
}

\author{
Jack E. Staub ${ }^{\mathbf{1}}$ and Matthew D. Robbins \\ U.S. Department of Agriculture, Agricultural Research Service, Forage and Range Research \\ Laboratory, 696 N. 1100 E., Logan, UT 84322 \\ Yingmei Ma and Paul G. Johnson \\ Plant, Soils, and Climate Department, Utah State University, Old Main Hill, Logan, UT 84322
}

\begin{abstract}
AdDitional InDEX words. abiotic stress tolerance, genetic analysis, AFLP
ABstract. Continued reduction in limited natural resources worldwide increasingly necessitates the incorporation of low-maintenance and low-input plant materials into urban landscapes. Some fine-leaved Festuca grass species have been used in formal gardens and native urban landscapes because of their inherent tolerance to abiotic stresses, but native, ornamental types (tall and non-spreading with multicolored culms and panicles) are not common in landscapes of the western United States. A native fine-leaved Festuca collection made in Montana (designated FEID 9025897) by the U.S. Natural Resources Conservation Services possesses such ornamental characteristics but has not been evaluated for its horticultural potential. Therefore, a study was designed to assess its phenotypic and genotypic attributes by cloning 270 FEID 9025897 plants and evaluating them along with native $F$. idahoensis and $F$. ovina PIs (five) and commercial checks (five) for genetic diversity and plant morphology for 2 years (2010-11). Plant genetic constitution was determined using amplified fragment length polymorphism (AFLP) analysis. Plant height, width, biomass, relative vigor (visual rating of $0=$ dead to $5=$ green, abundant growth), persistence (number of plants alive per plot), and regrowth after clipping (visual rating of $0=$ none to $5=$ most) were estimated by evaluation of plants under replication at Hyde Park, UT. Based on AFLP-based coancestry analysis, FEID 9025897 plants possessed considerable genetic affinities with $F$. idahoensis. Morphological traits as averaged over both years varied in height $(13.9$ to $105.0 \mathrm{~cm})$, width $(9.9$ to $66.2 \mathrm{~cm})$, biomass (0 to $170.4 \mathrm{~g})$, vigor $(0.2$ to 4.7$)$, persistence (0 to 3.9), and regrowth (0 to 4.0). Based on these differences, 19 (7\%) FEID 9025897 plants were identified for their ornamental potential that possessed multicolored (red, orange, and yellow) culms and varied in morphology with 2-year means of height $(79.8 \mathrm{~cm})$, width $(45.2 \mathrm{~cm})$, biomass $(88.5 \mathrm{~g})$, vigor $(2.9)$, persistence $(1.8)$, and regrowth $(3.7)$.
\end{abstract}

The popularity of ornamental grasses for use in urban landscapes, parks, median strips, parking lot borders, and for erosion control on slopes has increased in recent years (Loram et al., 2008; Wilson and Knox, 2006). This increase is partially the result of the broad range of flowering times, panicle size, leaf width and color, and plant form of modern cultivars, which allows for their use in horticultural applications ranging from formal gardens to informal native urban landscapes (Wilson and Knox, 2006). Such plantings are considered to be an integral part of ecological systems worldwide, where they provide immeasurable aesthetic value (Waliczek et al., 2005; York, 2001) and considerable economic return to a range of horticultural industries (Hughes and Hinson, 2000; Johnson and Christensen, 1995; Meyer, 2011; Rathwell et al., 1995).

Native and non-native grasses are considered central to many U.S. urban landscapes (Beard and Green, 1994; Fender, 2008). In the western United States [U.S. Department of Agriculture (USDA) hardiness zones 3 to 5; annual precipitation 254 to $610 \mathrm{~mm}$ ], little bluestem (Schizachyrium scoparium), western wheatgrass [Pascopyrum smithii (synonymous with Agropyron smithii)], prairie junegrass [Koeleria macrantha (synonymous

Received for publication 10 Mar. 2014. Accepted for publication 24 Sept. 2014. Mention of a trade name, proprietary product, or specific equipment does not constitute a guarantee or warranty by the U.S. Department of Agriculture and does not imply its approval to exclusion of other products that may be suitable. ${ }^{1}$ Corresponding author. E-mail: jack.staub@ars.usda.gov. with $K$. cristata)], needlegrass (Stipa spartea), buffalograss (Buchloe dactyloides), and blue grama (Bouteloua gracilis) are being increasingly used for low-input urban horticultural applications (Wilson, 2011). To a lesser extent, fine-leaved fescue species are being considered for these low-input situations (Ruemmele et al., 2003) and in more purely ornamental applications [e.g., blue fescue (F. glauca); Neal and Senesac, 1991].

The genus Festuca contains $\approx 300$ genetically diverse, perennial species with both wide and narrow leaves and can have tufted or rhizomatous growth habits. Several species possess drought tolerance and have attributes useful for lowinput applications (Ruemmele et al., 2003). For instance, some Festuca species are used worldwide as turfgrass \{e.g., F. rubra (red fescue), $F$. ovina (sheep fescue), $F$. arundinacea [tall fescue (synonymous with Schedonorus arundinaceus)]\}, for roadsides [e.g., F. ovina, F. trachyphylla (hard fescue)], and in rangeland restoration $\{$ e.g., $F$. ovina, F. scabrella [altai fescue (synonymous with $F$. altaica)] (Johnson 2003; Ruemmele et al., 1995). Blue fescue is the only fine-leaved fescue widely used in the western United States as an ornamental for lowinput applications (e.g., 'Elijah Blue' and 'Casca11'; Blom, 2013). Because the taxonomy of Festuca grasses is ambiguous (Aiken et al., 1992; Darbyshire and Pavlick, 2007; Huff and Palazzo, 1998; Loureiro et al., 2007), there have been several taxonomic classifications of fine-leaved Festuca species (e.g., Darbyshire and Pavlick, 2007; Hultén and Fries, 1986; 
Tutin et al., 1993). The taxonomic treatment of Catalán et al. (2004) is used herein in the broad sense along with the treatment of Darbyshire and Pavlick (2007) because of its historical context to North American flora and its recognition of Festuca species worldwide. Where possible, other species designations are also cited to provide continuity with other taxonomic treatments.

Several fine-leaved Festuca species form a closely related polyploid aggregate often called the Ovina Complex with a basic chromosome number of $2 n=2 x=14$ (Darbyshire and Warwick, 1992; Jones et al., 2008; Ma, 2012; Pavlick, 1984). The Ovina Complex is composed of $F$. valesiaca [volga fescue (ploidy of $2 x$ to $6 x)$ ], $F$. filiformis [hair fescue $(2 x)$ ], $F$. idahoensis [idaho fescue $(4 x)], F$. ovina $(2 x$ to $6 x)$, $F$. roemeri [roemer's fescue $(4 x$ to $6 x)$ ], F. trachyphylla $(6 x)$, and $F$. viviparoidea ssp. viviparoidea [northern fescue (4x to $6 x)$ ]. Festuca idahoensis, $F$. roemeri, and $F$. viviparoidea ssp. viviparoidea are species considered native to the western United States.

In 1982, the U.S. Natural Resources Conservation Services (NRCS) Bridger Plant Materials Center (BPMC) collected seed from a native fine-leaved Festuca population in a semiarid region near Busby, MT, and designated it FEID 9025897. Because historical information about this population is limited, very little is known about the genetic or morphological characteristics of this plant material. Using five plants of FEID 9025897 in an AFLP-based analysis, Jones et al. (2008) reported that this population possessed relatively close genetic affinities with $F$. ovina. In 2009, the USDA Forage and Range Research Laboratory (FRRL) identified plants of FEID 9025897 in a Logan, UT, field nursery that were vigorous, relatively tall, and possessed desirable horticultural characteristics [J.E. Staub, unpublished data (Fig. 1)]. These preliminary observations suggested that selections from this population might have potential for low-input urban horticultural applications in the western United States. Thus, a replicated field trial was designed to assess the inherent phenotypic variation of the population and identify potentially useful and/or novel genotypes that require further multi-location evaluations for urban landscape applications. As a secondary objective, AFLP markers were used to characterize the genetic constitution of the population to provide information on its putative genetic ancestry and relatedness to $F$. idahoensis and $F$. ovina.

\section{Materials and Methods}

Germplasm. Seed of FEID 9025897 was originally collected (more than 10 plants) by the BPMC on the Charles E. Helvey Ranch east of the Rosebud River (T7S R39E NW1/4Sec

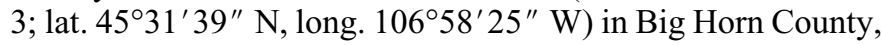
MT. This collection site has since been disturbed and the original plant material is no longer available. Seed of the initially collected population was field increased by the BPMC in 1994 and received by the FRRL in 2004. Historical information about the population is limited and the ancestry of plants in this population is unknown. Fine-leaved $F$. ovina and $F$. idahoensis populations exist throughout this region of Montana (Darbyshire and Pavlick, 2007) and, thus, could be progenitors of FEID 9025897.

Seven F. idahoensis accessions, 'Nezpurs' [PI 601053 (ploidy of 4x)], 'Joseph' [PI 601054 (4x)], PI 344597 (4x), PI $344604(4 x)$, PI 344609 (4x), PI 344614 (4x), and PI 344631 $(4 x)$, and three $F$. ovina cultivars, Durar [PI $578732(6 x)$ ], Covar

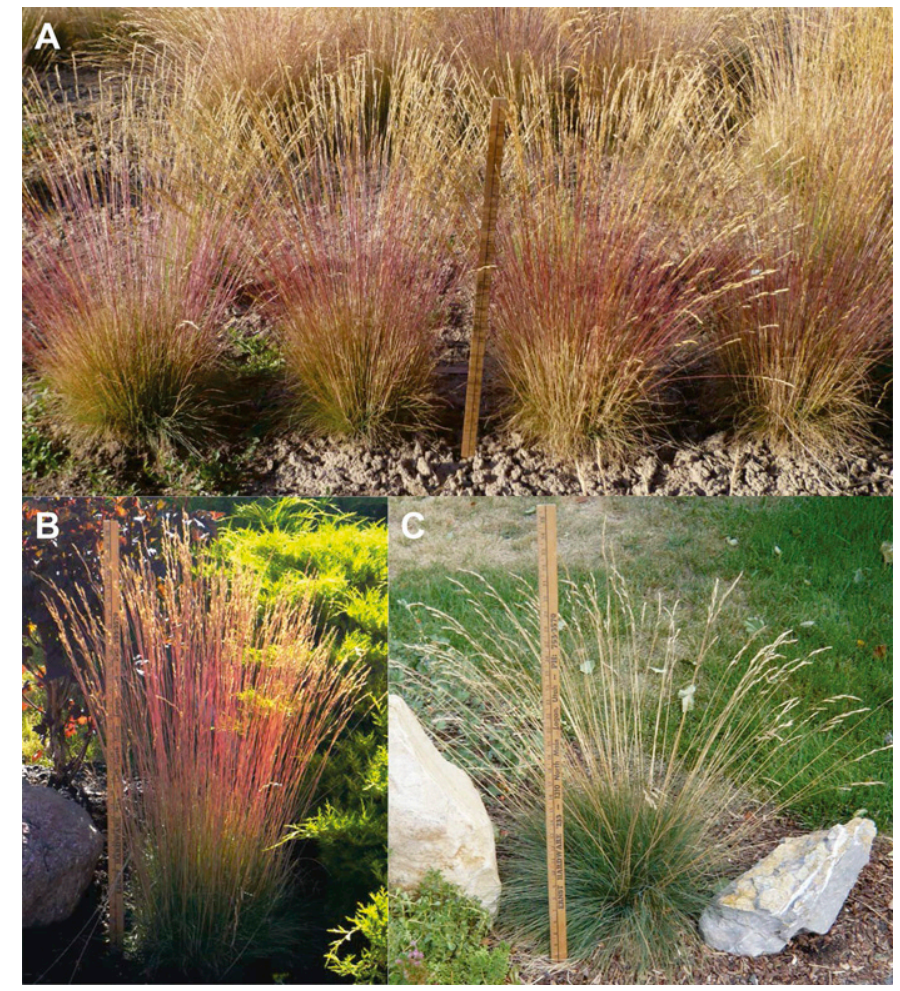

Fig. 1. Examples of selections for red coloration and plant habit within a putative Festuca idahoensis $\times$ F. ovina population, FEID 9025897 originating in Montana: (A) upright and inclined plant habits, (B) upright habit, (C) demonstrates pendulant inflorescences.

[PI $578733(2 x)$ ], and Bighorn [PI $549274(6 x)$ ], were used as checks (Table 1). Because the original plant material no longer exists, these checks were chosen to represent the genetic variation of these species in the United States, especially the F. ovina cultivars because they are widely distributed. Seed of all checks were obtained from the USDA Agricultural Research Service (ARS) Germplasm Resources Information Network (GRIN, 2013). Although 'Durar' is sometimes classified under several species names (e.g., $F$. trachyphylla, $F$. lemanii, $F$. ovina, $F$. brevipila), here it will be referred to as $F$. ovina sensu lato (sheep fescue in the broad sense) following Jones et al. (2008) because it is indistinguishable from $F$. ovina (Ma, 2012).

Plot establishment and maintenance. In Jan. 2008, seeds from the FEID 9025897 population were germinated on blotter paper, and then seedlings were planted in 164-mL nursery containers (Conetainers; Stuewe and Sons, Tangent, OR) containing a mixture $(\mathrm{v} / \mathrm{v})$ of $3: 1$ pumice and peatmoss in a greenhouse in Logan, UT. Seedlings were grown at $21^{\circ} \mathrm{C}$ day/ $15^{\circ} \mathrm{C}$ night with supplemental light supplied by high-pressure sodium lights [average irradiance $=400 \mathrm{~W}\left(1800 \mu \mathrm{mol} \cdot \mathrm{m}^{-2} \cdot \mathrm{s}^{-1}\right)$; Sun System III, Sunlight Supply, Vancouver, WA] at a relative humidity between $50 \%$ and $70 \%$. Seedlings were fertigated daily with $20 \mathrm{mg} \cdot \mathrm{mL}^{-1}$ of $20 \mathrm{~N}-8.7 \mathrm{P}-16.6 \mathrm{~K}$ water-soluble fertilizer (Peters Professional; Scotts, Marysville, $\mathrm{OH}$ ) to provide $4.0 \mathrm{mg} \cdot \mathrm{mL}^{-1}$ nitrogen, $1.7 \mathrm{mg} \cdot \mathrm{mL}^{-1}$ phosphorus, and $3.3 \mathrm{mg} \cdot \mathrm{mL}^{-1}$ potassium.

A total of 270 plants from the FEID 9025897 population were vegetatively cloned (12 clones per plant) for a replicated trial. Commercial cultivars (Bighorn, Joseph, Nezpurs, Durar, Covar) and PI accessions [10 checks (Table 1)] used as checks were grown from seed as described previously for individuals 
Table 1. PI accessions obtained from the U.S. Department of Agriculture, Agricultural Research Service, Genetic Resources Information Network (GRIN) used as checks for morphological evaluation of a U.S. native Festuca idahoensis $\times$ F. ovina grass population.

\begin{tabular}{|c|c|c|c|c|c|}
\hline Accession $^{z}$ & Scientific name & Common name & Cultivar & Origin & ID type ${ }^{y}$ \\
\hline PI 344597 & F. idahoensis & Idaho fescue & & Idaho & $\overline{\text { Collector }}$ \\
\hline PI 344604 & F. idahoensis & Idaho fescue & & Idaho & Collector \\
\hline PI 344609 & F. idahoensis & Idaho fescue & & Washington & Collector \\
\hline PI 344631 & F. idahoensis & Idaho fescue & & Montana & Collector \\
\hline PI 549274 & $F$. ovina & Sheep fescue & Bighorn & Oregon & Cultivar \\
\hline PI 601054 & F. idahoensis & Idaho fescue & Joseph & Idaho & Cultivar \\
\hline PI 578732 & F. ovina & Sheep fescue & Durar & Oregon & Cultivar \\
\hline PI 578733 & F. ovina & Sheep fescue & Covar & Turkey & Cultivar \\
\hline
\end{tabular}

${ }^{\mathrm{z}}$ Accessions are heterogeneous and heterozygous populations obtain from GRIN.

${ }^{\mathrm{y}}$ ID type as per classification under the GRIN system.

of the FEID 9025897 population. Because of their mode of reproduction (intermating with limited self-pollination), the checks must be considered heterogeneous and heterozygous. Thus, to represent their total inherent genetic variability during morphological evaluation, checks were established from seed and not from clones. Clones of the population and seedlings of the checks were transplanted in May 2008 to a field nursery in Hyde Park, Cache County, UT (lat. 41 $48^{\prime} 41.22^{\prime \prime} \mathrm{N}$, long. $\left.111^{\circ} 49^{\prime} 18.83^{\prime \prime} \mathrm{W}\right) \approx 8 \mathrm{~km}$ north of Logan, UT (elevation = $1383 \mathrm{~m}$ ), where the average annual precipitation during the experiment (2009-11) was $\approx 508 \mathrm{~mm}$ (average 20 -year precipitation is $453 \mathrm{~mm}$ ). The soil type was a Nibley fine mixed mesic (Aquic Argiustolls) having a neutral to slightly acidic $\mathrm{pH}$ (USDA, 2014). Plants were arranged in a randomized complete block (RCB) design with four clones or seedlings per plot in three replications and were spaced $0.5 \mathrm{~m}$ within the rows and $0.75 \mathrm{~m}$ between rows $(\approx 26,667$ plants $/$ ha $)$ with additional plants used as end and side borders. Although plants were given water at transplanting, no water or fertilizer was applied during the experiment, and plots were hand-weeded each year from May to August. Broadleaf weeds were also controlled with herbicide [mixture of 30.56\% 2,4-dichlorophenoxyacetic acid (2,4-D), 8.17\% mecoprop-p, and 2.77\% dicamba (MEC Amine-D; Loveland Products, Greeley CO)] application once in April or May of each year at a rate of $3.0 \mathrm{~g} \cdot \mathrm{ha}^{-1} 2,4-\mathrm{D}$, $0.8 \mathrm{~g} \cdot \mathrm{ha}^{-1}$ mecoprop-p, and $0.3 \mathrm{~g} \cdot \mathrm{ha}^{-1}$ dicamba.

Phenotypic trait evaluation. On 18 June 2010 and 12 May 2011, the relative plant vigor of all accessions was assessed using a 11-point visual rating scale from 0 to 5 (0.5 as units), where plant vigor (size, color, and transition from winter to spring growth) was defined as $0=$ dead plant, $2.5=$ plant possesses moderate biomass with some green foliage (tussock evident), and $5=$ green plants having comparatively abundant above-ground biomass. On 28 June 2010 and 20 June 2011, the height (centimeters) of each plant was measured as the distance from the plant base (soil surface) to the top of the highest floret at full anthesis (florets were gathered and straightened upward for measurement). Leaves and seed spikes were gathered together by hand and harvested $\approx 10 \mathrm{~cm}$ above ground when culms were dry and just before seed shattering (seed maturity), and then oven-dried at $60{ }^{\circ} \mathrm{C}$ to estimate plant biomass as total above-ground dry weight (grams). After above-ground harvesting, plant width was measured as the diameter of the remaining leaves and stems. For plots harvested in 2010 , dried florets of each plant were mechanically threshed to separate mature seeds and chaff (i.e., stalks and poorly developed or aborted seeds) for dry weight determination. Nevertheless, plants in a great majority of plots $(\approx 97 \%)$ did not appear to produce mature seed (i.e., florets were flat with no or vestigial embryos), an observation that was subsequently confirmed visually in 2011. Thus, seed was not threshed in 2011 and seed yield data are not presented. On 18 Nov. 2010 and 4 Nov. 2011, plants were visually rated on the same 11-point scale for regrowth, where $0=$ no regrowth, $2.5=$ comparatively moderate regrowth, and $5=$ most regrowth. Persistence was determined by counting the number of plants alive within each plot ( 0 to 4$)$ at the time when regrowth ratings were taken. Culm coloration was initially not one of the traits evaluated, but observations were noted on a few specific plots in July 2010 that were striking in color. Because brown/tan, yellow, orange, and maroon colors were also observed along the length of culms (Fig. 1) in July 2011, more extensive notes were recorded on specific plots, but the entire trial was not formally evaluated for this trait. Although selections were largely based on traits other than culm color, this was an important consideration because selections were made only from plots with attractive culm color.

Seed viability was not a characteristic originally considered for evaluation of the FEID 9025897 population, but it became necessary to measure this trait to address seed sterility. To determine relative seed viability, seed germination was measured in four cultivar checks (Covar, Durar, Joseph, and Nezpurs) and 34 FEID 9025897 individuals. This population subset of FEID 9025897 was chosen to represent the range of phenotype (morphological traits) and genotype (AFLP-based ancestry coefficients; see subsequently) detected. Germination for each accession was measured as the emergence of the radicle in three samples (replications) taken from each of three replications harvested in 2010. One hundred seeds from each plot were placed on seed germination paper (Steel Blue blotter paper, $178 \mathrm{~g} \cdot \mathrm{m}^{-2}$; Anchor Paper Co., St. Paul, MN) inside plastic germination boxes $(110 \times 110 \times 29 \mathrm{~mm})$, moistened with $\approx 12 \mathrm{~mL}$ of distilled water, and then misted once with chlorothalonil fungicide $(0.9 \%$ solution, Daconil; TechPac, Lexington KY). Seeds were then stored at room temperature $\left(\approx 23{ }^{\circ} \mathrm{C}\right)$ and the number of seeds germinated was recorded daily for 4 weeks. The germination rate was calculated as the mean percent germination of the three replications.

Phenotypic trait analysis. Morphological trait data (over 2 years) were analyzed using a linear mixed models analysis 
under which residuals for all traits were tested for normality using PROC UNIVARIATE in SAS software (Version 9.3 for Windows; SAS Institute, Cary, NC). Homogeneity of variance was evaluated by plotting the residuals against the predicted values. Year effects were tested using a repeated-measures model with compound symmetry covariance structure. Year was assumed to be a fixed effect because inferences for years were limited to the 2 years (2010 and 2011) under evaluation (Smith and Casler, 2004) and these 2 years may not be representative of multiple growing seasons of perennial species. Accession was assumed to be fixed because inferences were made for the specific accessions evaluated. Replicates were considered random effects. Year and accession main effects and the year $\times$ accession interaction effect were first tested under the repeated-measures model using PROC MIXED in SAS software. If year and/or year year $\times$ accession interaction effects were significantly different from zero, accession effects were then tested within each year as a RCB design using PROC MIXED in SAS. Accession means were separated using Fisher's protected least significant difference test by applying the lsmeans statement in SAS. Multivariate principal component analysis (PCA) was performed on lsmean values of all traits using PROC FACTOR in SAS to define accession relationships and to identify those traits that led most to accession discrimination (Kutner et al., 2004). Pearson product-moment correlation coefficients were produced using PROC CORR in SAS to assess the strength of associations among the traits examined (Székely et al., 2007).

DNA EXTraction AND AFLP ANALysis. Leaf samples from at least 15 plants of each accession were collected, lyophilized, and then ground into fine powder with zinc beads inside extraction tubes using a mixer mill (Model MM 300; F. Kurt Retsch, Haan, Germany). Total cellular DNA was extracted using a DNA extraction kit (DNeasy Plant Mini Kit; QIAGEN, Venlo, The Netherlands) according to the manufacturer's instructions and quantified with a spectrophotometer (NanoDrop ND-1000; Thermo Fisher Scientific, Waltham, MA). The AFLP polymerase chain reaction (PCR) amplification procedure was performed following Vos et al. (1995) with fluorescently labeled primers, size fractionating, and fragment size analysis according to Jones et al. (2008). The same E.AC/ M.CT primers defined by Jones et al. (2008) were used for preamplification, whereas the primer combinations of E-ACAC/ M-CTAC, E-ACAG/M-CTCA, E-ACCA/M-CTAG, E-ACCA/ M-CTTC, E-ACCT/M-CTCT, E-ACTC/M-CTTG, E-ACT/MCTA, E-ACT/M-CTG, E-ATA/M-CAA, and E-AGG/M-CGC were used for selective amplification. Approximately $4 \%$ of the samples were replicated to identify reproducible marker bands and determine marker error rates. Only the most distinct (i.e., bright) and reproducible (i.e., consistent during repeated PCR amplicon analysis) bands were used for analysis.

AFLP-Based Cluster anAlysis. Genetic relationships among individuals in the population and checks for each species (Table 1) were characterized using AFLP fragment data matrices [AFLP band present (1) or absent (0)] with Bayesian cluster analysis according to Falush et al. (2003) and Pritchard et al. (2000) using the program Structure Version 2.3.1 (Pritchard et al., 2000). Genetic relationships were defined by three iterations of Markov chain modeling (10,000 burn-in period, 100,000 Monte Carlo convergence permutations) where $\mathrm{K}=2$ using the recessive model to determine the proportion of the two parental species ( $F$. idahoensis and $F$. ovina) for each individual in the population.

Ploidy estimation. The ploidy level of 16 selected FEID 9025897 plants (Table 2) and all PI accession checks was determined by flow cytometry using a 4',6-diamidino-2-phenylindole staining kit (CyStain ultraviolet precise P; Partec, Munster, Germany) to extract and stain nuclei according to the manufacturer's protocol. Rapidly growing and immature leaves from each accession were harvested, pooled with leaves from a diploid $(2 n=2 x=14)$ control [W6 30595 ( $F$. valesiaca); Ma, 2012], and macerated in $400 \mu \mathrm{L}$ of extraction buffer. After incubation for 30 to $60 \mathrm{~s}$, the macerated tissue solution was filtered through a disposable filter (30 $\mu \mathrm{m}$ CellTrics; Partec), $1.6 \mathrm{~mL}$ of staining solution was added, and the resulting cell suspension was taken to the Utah State University Center for Integrated BioSystems (Logan) for fluorescence-based flow cytometry analysis (FACSAria II; Becton, Dickinson and Co., Franklin Lakes, NJ). Several checks with known ploidy levels were included to validate flow cytometry results. Plant Variety Protection certificates available from the GRIN indicate that 'Joseph' (PI 601054, PVP no. 8400003) and 'Nezpurs' (PI 601053; PVP no. 8400002) are $4 x$, whereas 'Bighorn' (PI 549274, PVP no. 8800064) is $6 x(\mathrm{GRIN}, 2013)$. The reported ploidy of 'Covar' is $2 x$ (Huff and Palazzo, 1998), whereas Ma (2012) designated 'Durar' as $6 x$ and PI 344631 as $4 x$. To further access methodological repeatability, $\approx 15 \%$ of the samples were randomly chosen and evaluated at least twice. If a notable inconsistency was observed in any sample examined, the cytometry analysis was repeated until unambiguous results were obtained. If a sample:control ratio equaled $1,1.5,2$, or 3 , the sample was declared as a diploid, triploid, tetraploid, or hexaploid, respectively.

\section{Results}

Phenotypic trait evaluation. The repeated-measures analysis over both years (2010 and 2011) identified significant main effects of year and accession as well as year $\times$ accession interaction effects. The main effect of accession was highly significant $(P<0.0001)$ for all traits. The probability values for the main effect of year were 0.196 for plant height, 0.015 for plant width, 0.914 for plant biomass, 0.001 for relative vigor, 0.001 for persistence, and $<0.0001$ for regrowth. The year $\times$ accession interaction probability values were $<0.0001$ for height, 0.070 for width, 0.011 for biomass, $<0.0001$ for vigor, 1.0 for persistence, and $<0.0001$ for regrowth. Morphological values among the plants examined as averaged over both years varied in height $(13.9$ to $105.0 \mathrm{~cm})$, width $(9.9$ to $66.2 \mathrm{~cm})$, biomass ( 0 to $170.4 \mathrm{~g}$ ), vigor (0.2 to 4.7$)$, persistence (0 to 4.0 ), and regrowth (0 to 3.9) (Table 2$)$. However, because all of the traits had significant year and/or year $\times$ accession effects, the results are presented separately for each year based on the RCB model.

When compared over years, plant height, biomass, regrowth, and persistence means of all entries were similar in 2010 and 2011, whereas average plant vigor was comparatively higher in 2010 and average width was higher in 2011 (Table 2). Although the mean of selected plants tended to be higher than the overall mean for all traits over both years, these differences were not always statistically significant $(P<0.05)$. When compared with the control cultivars (Bighorn, Joseph, Nezpurs, Durar, and Covar), the mean of the selected plants tended to be similar for 


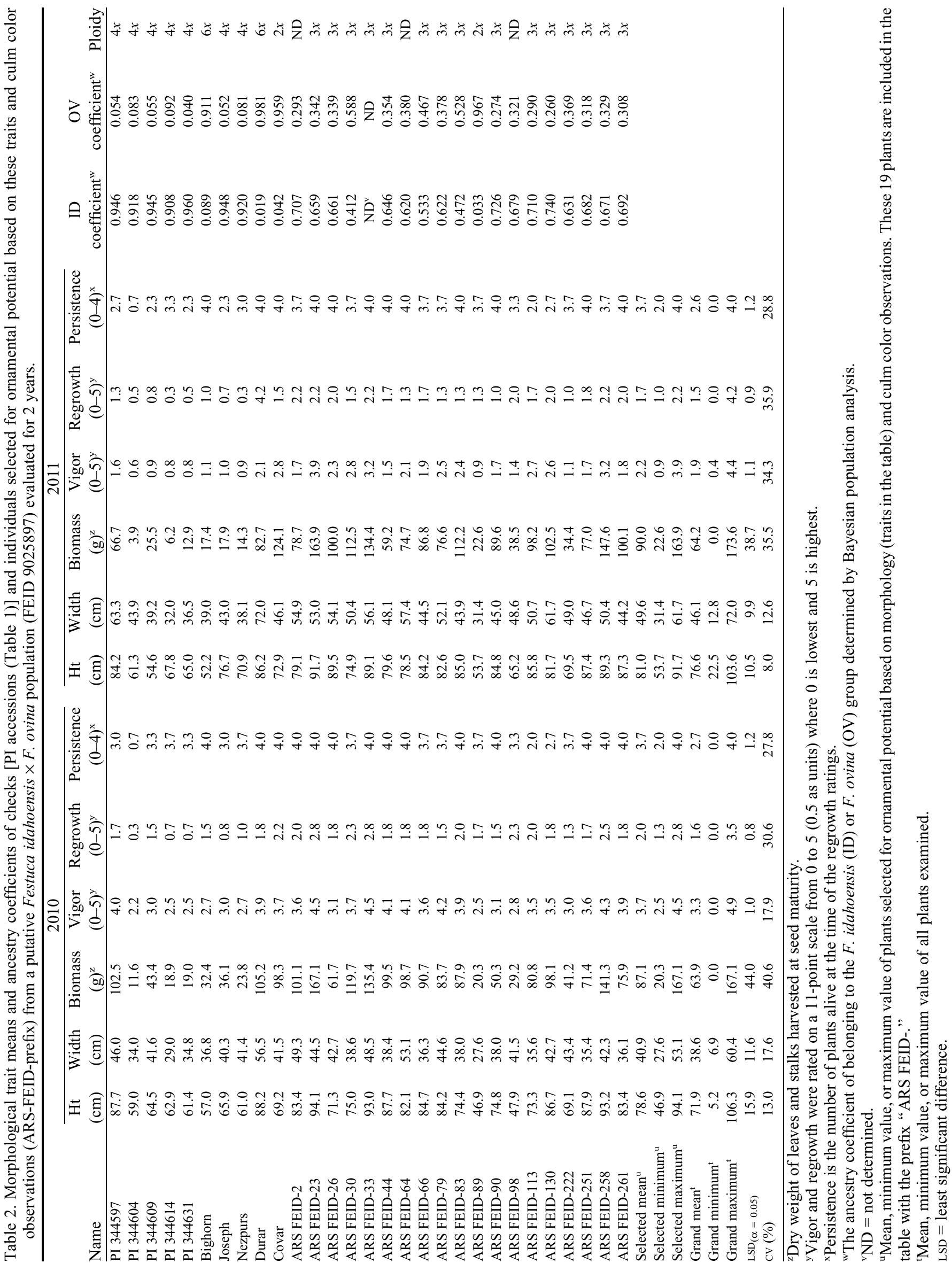


plant width and persistence over both years. For plant height, biomass, vigor, and regrowth, the selection means tended to be similar to 'Covar' and 'Durar', which were generally greater than 'Bighorn', 'Joseph', and 'Nezpurs'.

Several selected plants had high values over both years for multiple traits. For instance, ARS FEID-23 was relatively tall [94.1 (2010) and $91.7(2011) \mathrm{cm}$ ], large [biomass; $167.1(2010)$

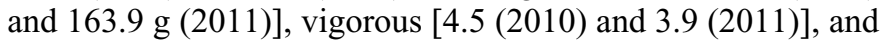
demonstrated good regrowth $[2.8$ (2010) and 2.2 (2011)] and persistence [4.0 (2010-11)]. Likewise, ARS FEID-33 performed well based on height [93.0 (2010) and 89.1 (2011) $\mathrm{cm}$ ], biomass [135.4 (2010) and $134.4 \mathrm{~g}$ (2011)], vigor [4.5 (2010) and 3.2 (2011)], regrowth [2.8 (2010) and 2.2 (2011)], and persistence [4.0 (2010-11)]. Similarly, ARS FEID-258 had relatively high values for height [93.2 (2010) and 89.3 (2011) $\mathrm{cm}]$, biomass [141.3 (2010) and $147.6 \mathrm{~g}$ (2011)], vigor [4.3 (2010) and 3.2 (2011)], regrowth [2.5 (2010) and 2.2 (2011)], and persistence $[4.0$ (2010) and 3.7 (2011)]. Although some selections had high values for one or two traits \{e.g., ARS FEID-64; width [53.1 (2010) and $57.4 \mathrm{~cm}$ (2011)] and persistence $[4.0(2010-11)]\}$, ARS FEID-23, ARS FEID-33, and ARS FEID-258 were high-performing selections considering all the traits examined.

Although seed germinated from all four checks, most individuals from the population did not produce viable seed. The seed germination rates of four cultivar checks were 55.3\% (Durar), 39.7\% (Joseph), 27.3\% (Covar), and 15.3\% (Nezpurs) (data not presented). None of the 300 seeds tested germinated from 28 of the 34 FEID 9025897 individuals. Germination rates of the other six plants were $0.3 \%$ (plants ARS FEID-21, ARS FEID- 94, and ARS FEID-232), 1.5\% (plant ARS FEID-49), $2.7 \%$ (plant ARS FEID-100), and 29.0\% (plant ARS FEID-53).

Trait Correlations. Significant $(P=0.001)$ and moderate $(r>0.62)$ to high $(r>0.71)$ correlations were detected between average biomass and height ( $r=0.79$ to 0.82$)$, width $(r=0.69$ to $0.73)$, vigor ( $r=0.89$ to 0.91$)$, and regrowth ( $r=0.62$ to 0.74$)$ in both years (Table 3 ). Likewise, significant correlations were also detected between plant height and vigor $(r=0.73$ to 0.91$)$ and width ( $r=0.69$ to 0.71$)$ in both years.

PrinicPal COMPonent analysis. Assessment of morphological relationships among checks and plants of FEID 9025897 by PCA explained $79.2 \%$ and $83.9 \%$ of the observed phenotypic variation (first two components) in 2010 and 2011, respectively (Fig. 2). Although no distinct groupings between accessions were detected, some consistently tall (plants ARS FEID-23, ARS FEID-33, and ARS FEID-258) and short (plants ARS FEID-89, ARS FEID-98, and ARS FEID-222) FEID 9025897 plants tended to cluster together irrespective of evaluation year. A total of 19 FEID 9025897 plants (7\% of the population) that varied in morphology [2-year means of height $(79.8 \mathrm{~cm})$, width $(45.2 \mathrm{~cm})$, biomass $(88.5 \mathrm{~g})$, vigor $(2.9)$, persistence $(1.8)$ and regrowth (3.7)] were selected primarily based on these traits (Table 2) and their culm color (red, orange, and gold). With the exception of culm color, selected plants generally tended to have morphological attributes similar to 'Durar' and 'Covar', whose culms were typically a light yellowish brown color. Selections were named with the prefix "ARS FEID-" to reflect their production by the USDA ARS and to retain the FEID label given to the population by the NRCS when originally collected and by Jones et al. (2008).

Genetic ANALysis. Bayesian AFLP-based analysis using the program Structure with $K=2$ allowed for the determination of the genetic proportion of each of the proposed parental species ( $F$. idahoensis and F. ovina) in each individual within the FEID 9025897 population. Based on AFLP banding similarities using nine primer combinations (778 bands), most FEID 9025897 plants $(93 \%)$ possessed genetic affinities with $F$. idahoensis, except for three selected (ARS FEID-30, ARS FEID-83, ARS FEID-89) and 10 unselected plants (Table 2; Fig. 3). In fact, the data indicate that only $16 \%$ of selected and $4 \%$ of the unselected plants possessed most of their DNA introgressed from $F$. ovina (hereafter designated as introgression DNA). Thus, the vast majority of FEID 9025897 plants were most similar in their inferred ancestry genome constitution to the $F$. idahoensis accessions examined.

Ploidy analysis. Ploidy was measured by fluorescencebased flow cytometry for all the checks and a subset of plants selected from the FEID 9025897 population. Our results (Table 2) matched the ploidy levels of the known checks, PI 344631 (4x), PI 601054 ['Joseph' (4x)], PI 601053 ['Nezpurs' (4x)], PI 549274 ['Bighorn' $(6 x)$ ], PI 578732 ['Durar' $(6 x)$ ], and PI 578733 ['Covar' $(2 x)$ ]. All the $F$. idahoensis checks were tetraploid, whereas the $F$. ovina checks were hexaploid ('Bighorn' and 'Durar') or diploid ('Covar'). Of the 16 individuals tested from the FEID 9025897 population, 15 were triploid, whereas only one plant, ARS FEID-89, was diploid.

\section{Discussion}

Over half of the world's population lives in an urban environment (Worldwatch Institute, 2007), where ornamental plants provide environments that encourage the presence of wildlife and plant diversity (Damschen et al., 2006) and offer a myriad of social and economic benefits (Lohr et al., 1996; Wolf, 2004). The economic importance of horticultural and turf products have increased steadily since 1970 such that the 12,962 businesses engaging in such activities in 1970 nearly doubled by 1998 and product sales from 1988 (\$4.8 million)

Table 3. Pearson correlation coefficients between morphological traits of Festuca idahoensis $\times$ F. ovina plants (population FEID 9025897) evaluated in 2010 (top diagonal) and 2011 (bottom diagonal).

\begin{tabular}{|c|c|c|c|c|c|c|}
\hline & $\mathrm{Ht}$ & Width & Biomass & Vigor & Regrowth & Persistence \\
\hline Height & & $0.687 * * *$ & $0.790 * * *$ & $0.906 * * *$ & $0.649 * * *$ & $0.350 * * *$ \\
\hline Biomass & $0.821 * * *$ & $0.725 * * *$ & & $0.892 * * *$ & $0.741 * * *$ & $0.301 * * *$ \\
\hline Regrowth & $0.542 * * *$ & $0.549 * * *$ & $0.617 * * *$ & $0.534 * * *$ & & $0.367 * * *$ \\
\hline Persistence & $0.255 * * *$ & $0.402 * * *$ & $0.327 * * *$ & $0.305 * * *$ & $0.145^{*}$ & \\
\hline
\end{tabular}

Coefficients are denoted with $P<0.0001(* * *)$ and $P<0.05(*)$. 

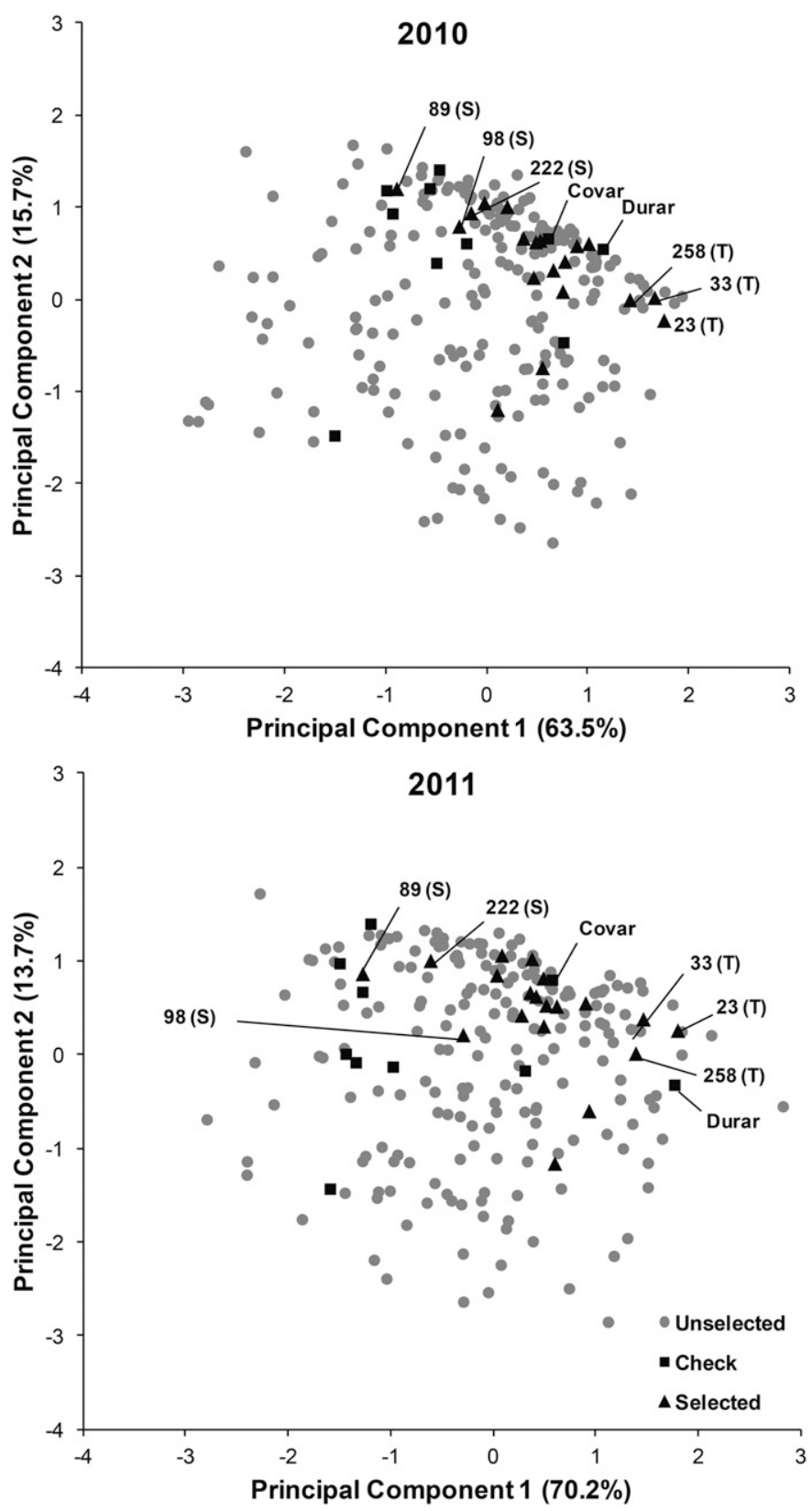

Fig. 2. Plot of the first two principal components from principal component analysis assessing a putative Festuca idahoensis $\times$ F. ovina population (FEID 9025897) and PI checks evaluated over 2 years (2010 and 2011) based on six morphological traits (Table 2). Percentage after axis titles indicates the percentage of variation explained by each principal component, and plants that were selected for further evaluation as well as those accessions that were consistently short (S) and tall (T) are indicated.

also doubled (Nursery Business Grower, 1995; Rathwell et al., 2001). This trend has continued and the value of horticultural specialty crops rose to $\$ 11.6$ billion in 2009 (U.S. Census Bureau, 2012). Ornamental grasses are an important component of this product mix [\$124 million (USDA, 2009)], where native and non-native germplasm provide a novel source of plant materials for direct application and plant improvement for low-input applications that enhance esthetic value and social interaction (Bradley and Hellier, 2011). We provide here the first report of the potential application of tall-statured, multicolored, native fine-leaved Festuca germplasm for such purposes in the western United States.

Nineteen selections (7\%) were made from the native Festuca population FEID 9025897 based on their genetic variation, plant architecture, and culm color observations (Table 2; Figs. 1 to 3 ). Although culm coloration was not formally evaluated in this population, non-rhizomatous plants were selected that produce showy red to orange culms (Fig. 1) originating from moderate-sized (28 to $62 \mathrm{~cm}$ in width) persistent green tussocks (Table 2). Such culm coloration in plants ranging between 47 and $94 \mathrm{~cm}$ in height is evident between early July to mid-August under non-irrigated northern Utah growing conditions. Plant height among the plants examined has a significant $(P<0.001)$ moderately positive correlation with width, biomass, vigor, and regrowth, but not necessarily persistence (Table 3 ). This suggests that, under the conditions examined, the most vigorous and tallest plants were not necessarily the most persistent. Thus, in conjunction with their potential release for Great Basin urban applications, additional multilocation evaluations will be needed to characterize their performance, including a more formal evaluation of culm color, under diverse growing environments.

These selections circumscribe the morphological variation present in the FEID 9025897 population plants studied and have, in the main, AFLP-based ancestry coefficients more similar to that of the $F$. idahoensis than to the $F$. ovina checks examined (Table 2; Fig. 3). Although these checks may not completely represent the plant material at or proximal to the original FEID 9025897 collection site, which is no longer available, the ancestry coefficients provide valuable baseline information on general relatedness of the population to $F$. idahoensis and F. ovina. Based on morphological traits (Fig. 2) and molecular marker assessment (Fig. 3), they do not fall into a distinct group when compared with the rest of the FEID 9025897 plants or checks examined. Nevertheless, some selections (e.g., plants ARS FEID-2 and ARS FEID-64) are taller in height, wider at the tussock base, and more vigorous than some of the checks examined. Similarly, some selections produce more regrowth and are more persistent (e.g., plants ARS FEID-2, ARS FEID-64, ARS FEID-83, ARS FEID-251, and ARS FEID-261) than some checks. These characteristics make some of these selections attractive for urban horticultural applications.

Seed recovered from semifertile FEID 9025897 plants in 2010 were poorly formed, not well developed, or both. However, these seed anomalies were not fully realized until after threshing, which occurred as much as 9 months after seed harvest. During the time interval between harvest and threshing, seed was held at room temperature $\left(\approx 23^{\circ} \mathrm{C}\right)$ under variable humidity $(20 \%$ to $50 \%)$. In addition, the inflorescences were oven-dried to obtain dry weight measurements, because seed germination was not originally planned as a measured characteristic. Although seeds germinated in cultivar checks (Durar, Covar, Joseph, and Nezpurs), their germination rate was relatively low (i.e., $15 \%$ to $55 \%$ ), which was most likely the result of handling and storage at less than optimal seed conditions. Nevertheless, the germination rates of the four checks were higher than population individuals, expect for plant ARS FEID-53. These results indicate that, although some individuals of FEID 9025897 possessed partial fertility, most were sterile. This contention was confirmed by phenotypic assessment of flower morphology and mature florets in 2011, 


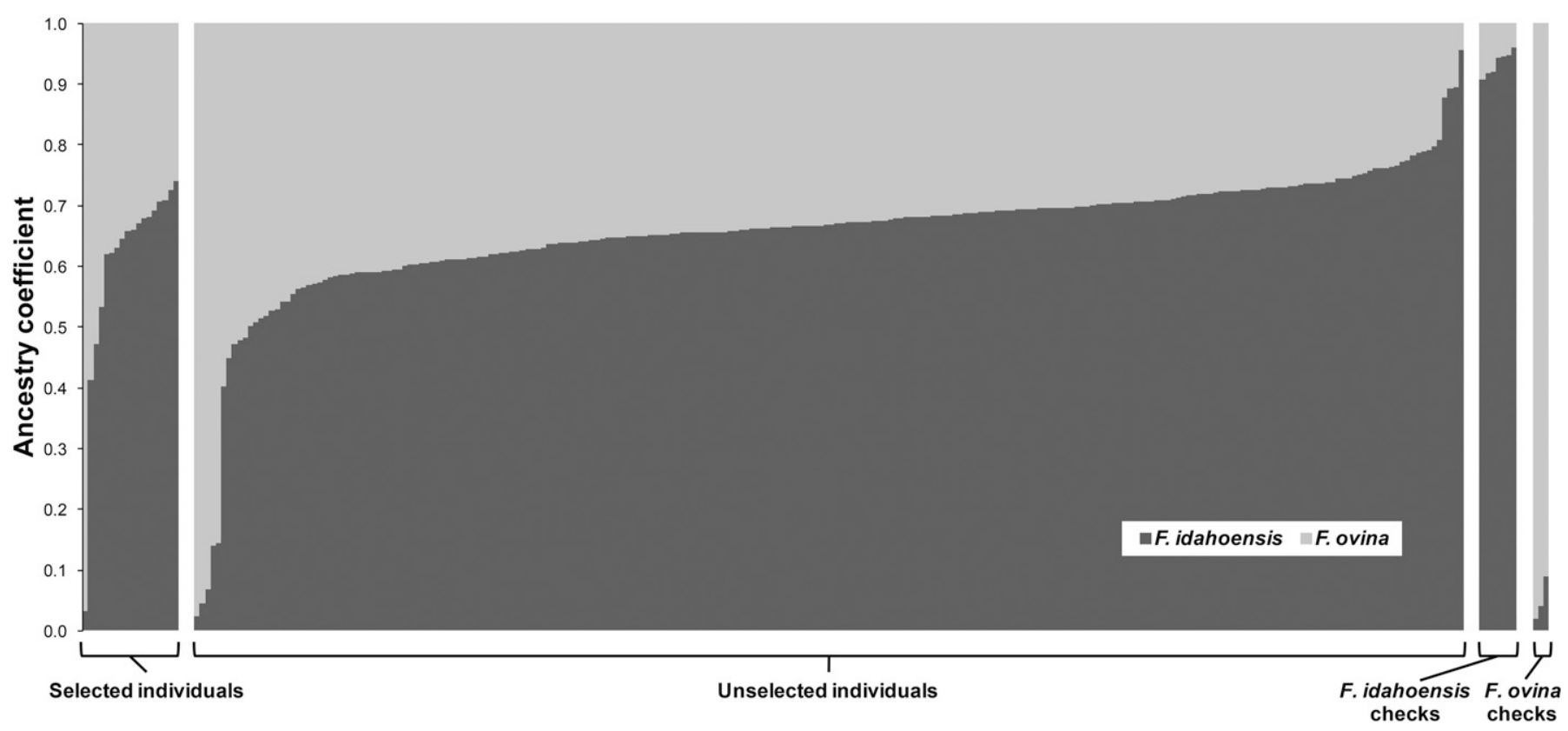

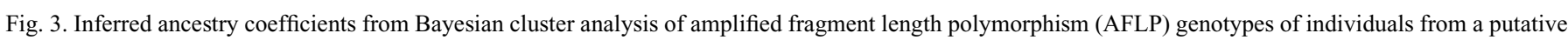
Festuca idahoensis $\times F$. ovina population designated FEID 9025897 . Selected individuals refers to individuals selected for ornamental potential based on morphology (Table 2) and culm color observations and unselected individuals refers to the rest of the population. Also included are $F$. idahoensis and $F$. ovina PI accessions and commercial cultivars used as checks (Table 1).

where a vast majority of the FEID 9025897 plants in Hyde Park and additional individuals of the same population at Blue Creek, UT [lat. $41^{\circ} 56^{\prime} 3.14^{\prime \prime} \mathrm{N}$, long. $112^{\circ} 26^{\prime} 20.01^{\prime \prime}$ W (data not presented)], demonstrated the presence of partial (dehiscence and pollen shed) or full sterility (no seed set).

The $F$. idahoensis ancestry coefficients (ACs) of the FEID 9025897 individuals that produced at least one viable seed [plants ARS FEID-21 (AC = 0.669), ARS FEID-94 (AC = 0.761), ARS FEID-232 (AC $=0.764)$, ARS FEID-49 $(\mathrm{AC}=0.895)$, ARS FEID-100 $(\mathrm{AC}=0.956)$, and ARS FEID-53 $(\mathrm{AC}=0.878)]$ were comparatively high, suggesting that individuals most genetically similar to the $F$. idahoensis accessions examined (Table 1) have a higher propensity to produce viable seed. In fact, the individuals with the highest germination rates (i.e., plants ARS FEID-100, ARS FEID-49, and ARS FEID-53) were morphologically similar to the $F$. idahoensis checks [i.e., short stature, relatively low biomass production (Table 2)]. Nevertheless, some individuals with relatively high $F$. idahoensis ancestry coefficients [e.g., plants ARS FEID-250 (AC $=0.808)$, ARS FEID-259 $(\mathrm{AC}=0.789)$, ARS FEID-32 $(\mathrm{AC}=0.737)$, ARS FEID-144 $(\mathrm{AC}=0.736)$, and ARS FEID-262 $(\mathrm{AC}=0.733)] \mathrm{did}$ not produce viable seed. These results indicate that seed germination is not necessarily correlated with the percentage of $F$. idahoensis genomic composition.

Flow cytometry has been effectively used to determine ploidy level in a broad array of species for taxonomic classification (Bennett and Leitch, 2011; Huff and Palazzo, 1998; Michaelson et al., 1991). Flow cytometry analyses of 16 plants selected from FEID 9025897 indicate that this population possesses mostly triploid and some diploid plants. Such genetic constitutions may provide an explanation for fertility differences detected among FEID 9025897 plants with similar ancestry coefficients (Table 2). The few individuals that produced viable seed were likely diploid, whereas the rest of the population was likely triploids. Moreover, because of the geographical origin of FEID 9025897, NRCS-BPMC FEID 9025897 associated collection notes (S. Williams, personal communication), the degree of cross-compatibility between native $F$. idahoensis and $F$. ovina (Jones et al., 2008; Ruemmele et al., 2003; Schmit et al., 1974), and the range of fertility observed in FEID 9025897 plants (this study), we hypothesize that this population originated from a naturalized mating between $F$. idahoensis $(4 x)$ and $F$. ovina $(2 x)$, resulting in partially and fully sterile triploid and possibly aneuploid progeny. Such a hybridization is predictable given the close genetic relationship between $F$. idahoensis and $F$. ovina (Darbyshire and Warwick, 1992; Jones et al., 2008). Interspecific and intergeneric hybrids, in fact, occur naturally in many tribes of the Poaceae (Cayouette and Darbyshire, 1993), and most polyploidy in turfgrass has evolved from such interspecific hybridizations, which subsequently led to stable amphiploids (Ruemmele et al., 2003). Although such derived amphiploids can be more vigorous and possess greater longevity when compared with their parents (Rieger et al., 1991), wide species crossing often results in cytogenetic complications (chromosome pairing) as a result of their low degree of chromosome homoeology [e.g., Elymus species and wheat (Triticum aestivum) (Lu and von Bothmer, 1991), buffalograss (Johnson and Riordan, 2001)].

Some triploid bermudagrasses have been derived from tetraploid by diploid hybridizations and are vegetatively propagated from stolons for commerce as warm-season turfgrasses (Busey, 1989). Similarly, many sterile, triploid bermudagrasses and fertile interspecific Poa hybrids [e.g., kentucky bluegrass $(P$. pratensis $) \times$ texas bluegrass $(P$. arachnifera $)]$ show potential for cool-season applications in suboptimal growing environments (Ruemmele et al., 2003). Some intergeneric and interspecific grass hybrids such as cogongrass (Imperata 
cylindrica) are, however, invasive weeds worldwide (Dozier et al., 1998; Holm et al., 1977), and, thus, prospective new and novel ornamental grasses must be well studied before commercial release.

Although the non-rhizomatous, sterile plants selected from the Festuca population FEID 9025897 should be non-invasive, they require broad-based multilocation evaluation to fully characterize their aesthetic value and potential for commercial propagation in the Great Basin. If these selections perform well in diverse, non-irrigated, semiarid environments and their propagation is deemed economical, then they should be considered for release as a novel native ornamental for lowinput urban applications in the western United States.

\section{Literature Cited}

Aiken, S.G., S.E. Gardiner, and M.B. Forde. 1992. Taxonomic implications of SDS-PAGE analyses of seed proteins in North American taxa of Festuca subgenus Festuca (Poaceae). Biochem. Syst. Ecol. 20:615-629.

Beard, J.B. and R.L. Green. 1994. The role of turfgrasses in environmental protection and their benefits to humans. J. Environ. Qual. 23:452-460.

Bennett, M.D. and I.J. Leitch. 2011. Nuclear DNA amounts in angiosperms: Targets, trends and tomorrow. Ann. Bot. (Lond.) 107:467-590.

Blom, A. 2013. Festuca plant named 'Casca11'. U.S. Patent no. PP23,307 P2. U.S. Patent and Trademark Office, Washington, DC.

Bradley, V.L. and J. Hellier. 2011. The U.S. cool-season grass collection: A source for novel ornamental grass germplasm. HortScience 46:S321 (Abstr.)

Busey, P. 1989. Progress and benefits to humanity from breeding warm-season grasses for turf, p. 49-70. In: Sleper, D.A., K.H. Asay, and J.F. Pedersen (eds.). Contributions from breeding forage and turf grasses. Crop Sci. Soc. Amer. Spec. Publ. 15. Amer. Soc. Agron., Madison, WI.

Catalán, P., P. Torrecilla, J.A. López-Rodríguez, and R.G. Olmstead. 2004. Phylogeny of the festucoid grasses of subtribe Loliinae and allies (Poeae, Pooideae) inferred from ITS and trnL-F sequences. Mol. Phylogenet. Evol. 31:517-541.

Cayouette, J. and S.J. Darbyshire. 1993. The intergeneric hybrid grass 'Poa labradorica'. Nord. J. Bot. 13:615-629.

Damschen, E.I., N.M. Haddad, J.L. Orrock, J.J. Tweksbury, and D.J. Levey. 2006. Corridors increase plant species richness at large scales. Science 313:1284-1286.

Darbyshire, S.J. and L.E. Pavlick. 2007. Festuca L., p. 389-443. In: Barkworth, M.E., K.M. Capels, S. Long, L.K. Anderton, and M.B. Piep (eds.). Flora of North America north of Mexico. Vol. 24. Oxford University Press, New York, NY.

Darbyshire, S.J. and S.I. Warwick. 1992. Phylogeny of North American Festuca (Poaceae) and related genera using chloroplast DNA restriction site variation. Can. J. Bot. 70:2415-2429.

Dozier, H., J.F. Gaffney, S.K. McDonald, E.R.R.L. Johnson, and D.G. Shilling. 1998. Cogongrass in the United States: History, ecology, impacts, and management. Weed Technol. 12:737-743.

Falush, D., M. Stephens, and K. Pritchard. 2003. Inference of population structure using multilocus genotype data: Linked loci and correlated allele frequencies. Genetics 164:1567-1587.

Fender, D.H. 2008. Urban turfgrasses in times of a water crisis: Benefits and concerns, p. 11-31. In: Beard, J.B. and M.P. Kenna (eds.). Water quality and quantity issues for turfgrasses in urban landscapes. CAST Spec. Publ. 27. Council Agr. Sci. Technol., Ames, IA.

Germplasm Resources Information Network. 2013. 19 Aug. 2014. $<$ http://www.ars-grin.gov/>.

Holm, L.G., D.L. Plucknett, J.V. Pancho, and J.P. Herberger. 1977. The world's worst weeds: Distribution and biology. Univ. Press of Hawaii, Honolulu, HI.
Huff, D.R. and A.J. Palazzo. 1998. Fine fescue species determination by laser flow cytometry. Crop Sci. 38:445-450.

Hughes, D.W. and R.A. Hinson. 2000. Estimating the value of the green industry to Louisiana's economy. J. Agribusiness 18:207-220.

Hultén, E. and M. Fries (eds.). 1986. Atlas of North European vascular plants (North of the Tropic of Cancer). Vols. I-III. Koeltz Scientific Books, Königstein, Germany.

Johnson, D.C. and R.L. Christensen. 1995. The green industry today-Some issues and future prospects. J. Agribusiness 13:63-76.

Johnson, P.G. 2003. Mixtures of buffalograss and fine fescue or streambank wheatgrass as a low-maintenance turf. HortScience 38:1214-1217.

Johnson, P.G. and T.P. Riordan. 2001. Unbalanced chromosome number and inbreeding effects on fertility and plant vigor in buffalograss. Intl. Turfgrass Soc. Res. J. 9:176-179.

Jones, T.A., S.R. Larson, and B.L. Wilson. 2008. Genetic differentiation and admixture among Festuca idahoensis, F. roemeri, and $F$. ovina detected in AFLP, ITS, and chloroplast DNA. Botany 86:422434.

Kutner, M.H., C.J. Nachtsheim, and J. Neter. 2004. Applied linear regression models, p. 176-212. 4th Ed. McGraw-Hill/Irwin, New York, NY.

Lohr, V.I., C.H. Pearson-Mims, and G.K. Goodwin. 1996. Interior plants may improve worker productivity and reduce stress in a windowless environment. J. Environ. Hort. 14:97-100.

Loram, A., P.H. Warren, and K.J. Gaston. 2008. Urban domestic gardens (XIV): The characteristics of gardens in five cities. Environ. Mgt. 42:361-376.

Loureiro, J., D. Kopecký, S. Castro, C. Santos, and P. Silveira. 2007. Flow cytometric and cytogenetic analyses of Iberian Peninsula Festuca spp. Plant Syst. Evol. 269:89-105.

Lu, B.R. and R. von Bothmer. 1991. Production and cytogenetic analysis of the intergeneric hybrids between nine Elymus species and common wheat (Triticum aestivum L.). Euphytica 58:81-95.

Ma, Y. 2012. Genetic characterization of fine-leaved Festuca valesiaca germplasm and evaluation of their relationship to the $F$. ovina complex. Master thesis No. 1352; Utah State Univ., Logan. 4 Mar. 2014. <http://digitalcommons.usu.edu/etd/1352>.

Meyer, M.H. 2011. Ornamental grasses in the United States. Hort. Rev. 39:121-152.

Michaelson, M.J., H.J. Price, J.R. Ellison, and J.S. Johnston. 1991. Comparison of plant DNA contents determined by Feulgen microspectrophotometry and laser flow cytometry. Amer. J. Bot. 78:183188.

Neal, J.C. and A.F. Senesac. 1991. Preemergent herbicide safety in container-grown ornamental grasses. HortScience 26:157-159.

Nursery Business Grower. 1995. Nursery business grower 100. Nursery Business Grower magazine, Spec. Rpt. Brantwood Publications, Clearwater, FL.

Pavlick, L.E. 1984. Studies on the Festuca ovina complex in the Canadian Cordillera. Can. J. Bot. 62:2448-2462.

Pritchard, J.K., M. Stephens, and P. Donnelly. 2000. Inference of population structure using multi-locus genotype data. Genetics 155:945-959.

Rathwell, P.J., M.G. Evatt, and M.S. Henry. 2001. Contributions of the ornamental horticulture and turfgrass industry to the South Carolina economy, 1999. Clemson Univ. Dept. Agr. Appl. Econ., Ext. Econ. Rpt. 194.

Rathwell, P.J., M.S. Henry, D.L. Barkley, and M.G. Evatt. 1995. Contributions of ornamental horticulture and turfgrass industries to the state economy: South Carolina, 1994. Clemson Univ. Dept. Agr. Appl. Econ., Ext. Econ. Rpt. 160.

Rieger, R., A. Michaelis, and M.M. Green. 1991. Glossary of genetics (classical and molecular). 5th Ed. Springer-Verlag, New York, NY.

Ruemmele, B.A., L.A. Brilman, and D.R. Huff. 1995. Fine fescue germplasm diversity and vulnerability. Crop Sci. 35:313-316.

Ruemmele, B.A., J. Wipff, L.A. Brilman, and K. Hignight. 2003. Fineleaved Festuca species, p. 129-174. In: Casler, M.D. and R.R. 
Duncan (eds.). Turf-grass biology, genetics, and breeding. Wiley, Hoboken, NJ.

Schmit, R.M., R.W. Duell, and C.R. Funk. 1974. Isolation barriers and self-compatibility in selected fine fescues, p. 9-17. In: Roberts, E.C. (ed.). Proc. Second Intl. Turfgrass Conf., Intl. Turfgrass Soc., Amer. Soc. Agron., Crop Sci. Soc. Amer., Madison, WI.

Smith, K.F. and M.D. Casler. 2004. Spatial analysis of forage grass trials across locations, years, and harvests. Crop Sci. 44:56-62.

Székely, G.J., M.L. Rizzo, and N.K. Bakirov. 2007. Measuring and testing independence by correlation of distances. Ann. Stat. 35:2769-2794.

Tutin, T.G., V.H. Heywood, N.A. Burges, D.M. Moore, D.H. Valentine, S.M. Walters, and D.A. Webb (eds.). 1993. Flora Europaea. 2nd Ed. Cambridge Univ. Press, Cambridge, UK.

U.S. Census Bureau. 2012. The national data book, 2012 statistical abstract, Table 868. 4 Mar. 2014. <http://www.census.gov/compendia/ statab/cats/agriculture.html>.

U.S. Department of Agriculture. 2009. Census of horticultural specialties. State data, Table 24. 4 Mar. 2014. <http://www.agcensus.usda. gov/Publications/2007/Online_Highlights/Census_of_Horticulture_ Specialties>.

U.S. Department of Agriculture. 2014. Web soil survey. 10 Oct. 2014. $<$ http://websoilsurvey.nrcs.usda.gov/>.
Vos, P., R. Hogers, M. Bleeker, M. Reijans, T. van de Lee, M. Hornes, A. Frijters, J. Pot, J. Peleman, M. Kuiper, and M. Zabeau. 1995. AFLP: A new technique for DNA fingerprinting. Nucleic Acids Res. 23:4407-4414.

Waliczek, T.M., J.M. Zajicek, and R.D. Lineberger. 2005. The influence of gardening activities on consumer perceptions of life satisfaction. HortScience 40:1360-1365.

Wilson, C.R. 2011. Ornamental grasses. Colorado State Ext. Bul. 7.232. 4 Mar. 2014. <http://www.ext.colostate.edu/pubs/garden/ 07232.html>.

Wilson, S.B. and G.W. Knox. 2006. Landscape performance, flowering, and seed viability of 15 japanese silver grass cultivars grown in northern and southern Florida. HortTechnology 16:686-693.

Wolf, K.L. 2004. Trees, parking and green law: Strategies for sustainability. Georgia For. Commission, Urban and Community For., Stone Mountain, GA. 4 Mar. 2014. <http://www.naturewithin. info/Roadside/Trees_Parking_Green\%20Law.pdf $>$.

Worldwatch Institute. 2007. Cities key to tackling poverty and climate change. Worldwatch Inst., Washington, DC. 4 Mar. 2014. <http:// worldwatch.org/node/4839>.

York, K. 2001. The holistic garden: Creating spaces for health and healing. Prentice Hall, Toronto, Canada. 